\title{
Nervous System-Specific Expression of a Novel Serine Protease: Regulation in the Adult Rat Spinal Cord by Excitotoxic Injury
}

\author{
Isobel A. Scarisbrick, ${ }^{1,2}$ Melvin D. Towner, ${ }^{1}$ and Paul J. Isackson ${ }^{1}$ \\ ${ }^{1}$ Department of Biochemistry and Molecular Biology, Mayo Clinic, Jacksonville, Florida 32224, and ${ }^{2}$ Molecular \\ Neuroscience Research, Mayo Clinic Rochester, Rochester, Minnesota 55905
}

\begin{abstract}
A full-length cDNA clone of a previously unidentified serine protease, myelencephalon-specific protease (MSP), has been isolated by using a PCR cloning strategy and has been shown to be expressed in a nervous system and spinal cord-specific pattern. Sequence analysis demonstrated that MSP is most similar in sequence to neuropsin, trypsin, and tissue kallikrein and is predicted to have trypsin-like substrate specificity. MSP mRNA was found to be $\sim 10$-fold greater in the CNS of the rat and human, as compared with most peripheral tissues, and within the CNS was found to be highest by a factor of four in the medulla oblongata and spinal cord. Levels of mRNA encoding tissue plasminogen activator (tPA) also were elevated in the spinal cord but were more widespread in peripheral tissues as compared with MSP.

In the adult rat lumbosacral spinal cord, in situ localization of MSP mRNA demonstrated 2-fold higher levels in the white, as
\end{abstract}

compared with the gray, matter. MSP mRNA expression was shown to increase 3-fold in the white matter and 1.5-fold in the gray laminae at $72 \mathrm{hr}$ after intraperitoneal injection of the AMPA/ kainate glutamate receptor-specific agonist, kainic acid (KA). MSP mRNA remained elevated in the ventral gray matter, including expression associated with the motor neurons of lamina IX, at $7 \mathrm{~d}$ after the initial excitotoxic insult. Together, these observations indicate that MSP is in a position to play a fundamental role in normal homeostasis and in the response of the spinal cord to injury.

Key words: serine protease; spinal cord; brain stem; medulla oblongata; motor neuron; oligodendrocyte; CNS; excitotoxicity; kainic acid
Among factors likely to participate in the response of the nervous system to injury, including tissue degeneration, are changes in the constitution of a variety of extracellular matrix components (Sanes, 1983, 1989), growth factors (Barde et al., 1983), and cell proteolytic cascades (Krystosek and Seeds, 1981; Monard, 1988; Seeds et al., 1990). The activity of serine proteases and their inhibitors has been established to play important roles in the nervous system, including the regulation of neuronal migration during development (Moonen et al., 1982; Seeds et al., 1990), neurite outgrowth (Monard, 1988), synaptic plasticity (Liu et al., 1994a,b), and neuronal degeneration and death (Houenou et al., 1995; Tsirka et al., 1995, 1997). These actions may be mediated by the proteolytic cleavage of zymogen precursors and propeptides, the activation of specific cell surface receptors, and/or by the degradation of extracellular matrix proteins (Monard, 1988; Pittman and Williams, 1989; McGuire and Seeds, 1990).

Serine proteases that have been examined primarily in the nervous system include the plasminogen activators and thrombin, each of which has been shown to affect neuronal plasticity (Qian et al., 1993; Liu et al., 1994a; Seeds et al., 1995). The localized release of plasminogen activators by neuronal growth

\footnotetext{
Received June 10, 1997; revised Aug. 7, 1997; accepted Aug. 15, 1997.

This research was supported by the Mayo Foundation. I.A.S. was supported by a postdoctoral research fellowship from Nemours Children's Clinic. We acknowledge the contributions of C. Delcher, C. Tsai, M. Garcia, P. Tiseo, and M. Farrar to the progress of this work and Dr. A. J. Windebank for continued support of this research.

Correspondence should be addressed to Dr. Isobel A. Scarisbrick, Neuroscience Research, 1521 Guggenheim Building, Mayo Clinic Rochester, 200 First Street SW, Rochester, MN 55905.

Copyright (C) 1997 Society for Neuroscience $\quad 0270-6474 / 97 / 178156-13 \$ 05.00 / 0$
}

cones has suggested that their expression and subsequent degradation of extracellular matrix components is required for neurite outgrowth (Krystosek and Seeds, 1981). Tissue plasminogen activator (tPA) mRNA expression in hippocampal neurons is increased with afferent stimulation (Qian et al., 1993; Carroll et al., 1994), and, in the mouse mutant weaver, cerebellar neurons can be rescued from death in vitro by the serine protease inhibitor aprotinin (Murtomaki et al., 1995). Transgenic mice deficient in tPA exhibit an altered form of long-term potentiation (Frey et al., 1996) and are resistant to excitotoxic-mediated neuronal degeneration (Tsirka et al., 1995, 1997). Glial-derived protease nexin-I (PNI), a potent endogenous inhibitor of thrombin, specifically inhibits thrombin-induced neurite retraction (Gurwitz and Cunningham, 1988, 1990) and neuronal degeneration (Smith-Swintosky et al., 1995; Festoff et al., 1996). Additionally, PNI has been demonstrated to reduce axotomy-induced motor neuron death in the neonatal mouse and to prevent programmed cell death in the chick motor cell column when administered in ovo (Houenou et al., 1995).

To identify potentially important serine proteases in the normal and injured spinal cord, we designed a series of degenerate oligonucleotide primers based on regions of homology between known serine proteases, and we used them to PCR amplify protease cDNA clones from the nervous system. Using this strategy, we have identified a novel serine protease, myelencephalonspecific protease (MSP). In this report we describe the full-length sequence and expression of MSP mRNA in the nervous system and peripheral tissues of the rat and human, and we show that MSP expression in the adult rat spinal cord is upregulated dramatically after excitotoxic injury. 


\section{MATERIALS AND METHODS}

\section{Animal treatments}

Adult male Sprague Dawley rats (180-200 gm) obtained from Harlan Laboratories (Indianapolis, IN) were used throughout these experiments. Animals were administered $10 \mathrm{mg} / \mathrm{kg}$ kainic acid (KA) intraperitoneally and were observed for behavioral seizures. Control animals and animals at $12,24,48$, and $72 \mathrm{hr}$ and 1 week post-KA administration were anesthetized deeply with sodium pentobarbital $(35 \mathrm{mg} / \mathrm{kg})$ and perfused transcardially with $4.0 \%$ paraformaldehyde in $0.1 \mathrm{~m}$ phosphate buffer, $\mathrm{pH}$ 7.4. The lumbosacral spinal cord (L1-S4) was retrieved, cryoprotected in $0.1 \mathrm{M}$ phosphate buffer containing $20 \%$ sucrose, and cut in the transverse or sagittal plane at $20 \mu \mathrm{m}$ for in situ hybridization histochemistry. Alternatively, other groups of animals at the same time points were killed by $\mathrm{CO}_{2}$ gas and decapitation, followed by RNA isolation from whole brain, spinal cord, and peripheral tissues for cDNA cloning or Northern blot analysis.

\section{Isolation of MSP $c D N A$}

Clone pM444-4 was obtained by PCR of adult rat spinal cord first-strand cDNA, using degenerate oligonucleotides targeted to two highly conserved regions of the trypsin/chymotrypsin serine protease family. The sense strand primer (5'-TGGGTGATCACRGCTGCYCACTGC-3') corresponds to the coding region of amino acids 51-58 and the antisense primer (5'-GAGGGGSCCTCCTGAGTCACC-3') corresponds to the region of amino acids 193-199 of chymotrypsinogen (see Fig. 1). These regions flank the conserved His and Ser residues, respectively, of the active site catalytic triad of the chymotrypsin serine protease family. A 435 base pair (bp) cDNA fragment obtained after PCR (pM444-4) was cloned into pGEM-T (Promega, Madison, WI) and characterized by dideoxy nucleotide sequence analysis. Using a similar strategy, we obtained a cDNA clone, pCD2-1, from human cerebral cortex cDNA, which is $80 \%$ identical to pM444-4 at the nucleotide level and appears to be the human homolog of M444-4.

The full-length rat MSP (rMSP) cDNA was obtained by PCR, using rat brain MarathonReady cDNA and Advantage KlenTaq DNA polymerase (Clontech, Cambridge, UK). The polymerase was chosen for its ability to generate long amplifications and provide $3^{\prime}-5^{\prime}$ proofreading. Specific internal primers were designed that overlap the EcoRI restriction site in clone pM444-4. These primers, along with the supplied adaptorcomplementary primers, were used to generate both $5^{\prime}$ and $3^{\prime}$ fragments. Fractionation of the PCR products on a $1 \%$ agarose gel revealed a fragment of $\sim 800 \mathrm{bp}$ for the $5^{\prime}$ region and $650 \mathrm{bp}$ for the $3^{\prime}$ end. These fragments were cloned into pGEM-T. The $5^{\prime}$ fragment was excised from one of the resulting clones (pM500-5) with SacII and EcoRI and ligated into a similarly digested plasmid containing the $3^{\prime}$ fragment (pM502-1). The resulting clone, pM515-1, contained the full-length cDNA as determined by subsequent sequencing. The predicted amino acid sequence was screened for sequence homology with the Swiss Protein Database via the Basic Local Alignment Search Tool.

\section{MSP RNA expression in brain and peripheral tissues}

Northern hybridization. The abundance of MSP mRNA expression in the rat brain and spinal cord was quantified by Northern hybridization. The brain or spinal cord of control and KA-treated adult rats was homogenized in guanidine thiocyanate, and the RNA was pelleted through a cushion of $\mathrm{CsCl}$ (Chirgwin et al., 1979). mRNA was isolated from total RNA with Poly $\left(\mathrm{A}^{+}\right)$Tract (Promega). One microgram samples of mRNA were fractionated by electrophoresis in $1.4 \%$ agarose, followed by capillary transfer to Zetta membranes, using $10 \times$ saline sodium citrate (SSC; $1.5 \mathrm{M} \mathrm{NaCl}$ and $1.5 \mathrm{~m}$ sodium citrate) overnight. Transferred mRNA was cross-linked by baking at $80^{\circ} \mathrm{C}$ for $1 \mathrm{hr}$. The nylon membrane containing poly $\left(\mathrm{A}^{+}\right)$RNAs from eight different rat tissues (heart, brain, spleen, lung, liver, skeletal muscle, kidney, and testes) was obtained from Clontech. Each lane contained $\sim 2 \mu \mathrm{g}$ of poly $\left(\mathrm{A}^{+}\right) \mathrm{RNA}$ and was examined for the relative abundance of rat MSP and for the abundance of a known serine protease, tPA, by Northern hybridization. The distribution of MSP and tPA mRNA in human brain and peripheral tissues was explored by Northern hybridization of a multiple tissue RNA dot blot containing human poly $\left(\mathrm{A}^{+}\right)$RNA from 15 different human adult brain regions and 28 peripheral non-neural tissues (Clontech). The signal produced from a nontissue-specific constitutively expressed gene, ubiquitin, has been shown to be consistent for each dot containing RNA samples from different tissues.

Rat MSP (pM444-4) and human MSP (pCD-2) cDNA inserts were cut from plasmid DNA with a combination of $S p h \mathrm{I}$ and NcoI. A tPA cDNA fragment, corresponding to bp 1149-1603 (Rickles et al., 1988), was PCR-amplified from mouse brain cDNA and inserted into pGEM-T to create pM455. The mouse tPA cDNA insert was excised from pM455 with SpeI and NcoI. A 409 bp human tPA cDNA probe corresponding to bp 1134-1543 (Degen et al., 1986) was PCR-amplified from clone (40403; American Type Culture Collection, Rockville, MD). cDNA fragments were purified from $1 \%$ agarose gels (QIAEX II) and were labeled with 5 $\mu \mathrm{Ci}\left[\alpha_{-}{ }^{32} \mathrm{P}\right]$-ATP by random hexamer priming (Promega). Northern hybridization of mRNA blotted on Zetta membranes was performed according to Maniatis (Sambrook et al., 1989). Membranes containing RNA from rat CNS were hybridized for $24 \mathrm{hr}$ at $68^{\circ} \mathrm{C}$ with the radiolabeled cDNA probes in the presence of $0.04 \mathrm{M}$ sodium phosphate, $\mathrm{pH} 7.2$, 5\% SDS, $1 \mathrm{~mm}$ EDTA, $100 \mu \mathrm{g} / \mathrm{ml}$ denatured and sheared salmon sperm DNA, and Denhardt's $(5 \times)$. Filters were washed with $5 \%$ SDS, $1 \mathrm{~mm}$ EDTA, and $40 \mathrm{~mm}$ sodium phosphate, $\mathrm{pH} 7.2$, at $68^{\circ} \mathrm{C}$ and then at room temperature with $0.1 \%$ SDS, 1 mM EDTA, and 40 mM sodium phosphate, $\mathrm{pH} 7.2$, in diethylpyrocarbonate-treated water. Rat and human multiple tissue Northern blots were hybridized in Express Hybridization Solution (Clontech) and washed under similar conditions. All blots were viewed on a phosphorimager, and the relative optical density (ROD) of each band was determined with the Molecular Dynamics (Sunnyvale, CA) image analysis system for further quantification. Then blots were placed on x-ray film (XAR, Eastman Kodak, Rochester, NY) for exposures from $12 \mathrm{hr}$ to 1 week at $-70^{\circ} \mathrm{C}$, with two intensifying screens. The relative amount of MSP or tPA mRNA hybridization in each Northern blot was normalized for any differences in sample RNA loading by rehybridizing stripped membranes to one or more cDNA control probes. The control cDNAs used were EcoRI-digested cyclophilin (pML-20) (Danielson et al., 1988) and a human $\beta$-actin cDNA or a cDNA probe to the glycolytic enzyme glyceraldehyde-3-phosphate dehydrogenase (GAPDH), obtained from Clontech.

In situ hybridization histochemistry. Serial sections through the lumbosacral spinal cord (L1-S3) of control and KA-injected adult male rats were examined for the density and distribution of rMSP mRNA with in situ hybridization techniques. Frozen $20 \mu \mathrm{m}$ transverse or sagittal sections through the lumbosacral spinal cord were cut into $0.1 \mathrm{M}$ phosphate buffer and mounted on to Vectabond-coated (Sigma, St. Louis, MO) slides. Sections adjacent to those processed for in situ hybridization histochemistry were counterstained with $0.25 \%$ cresyl violet. Slides containing sections from either control or treated animals were hybridized in parallel for localization of $\left[\alpha-{ }^{35} \mathrm{~S}\right]-\mathrm{UTP}$-labeled antisense or sense strand rMSP cRNA. The rMSP plasmid (M444-4) was linearized with SacII for synthesis of the antisense riboprobe with T7 RNA polymerase or with SpeI for synthesis of the sense strand riboprobe with SP6 RNA polymerase (Stratagene, La Jolla, CA) in the presence of $\left[\alpha^{-}{ }^{35}\right.$ S]-UTP (Amersham, Arlington Heights, IL). Hybridization histochemistry was performed as previously reported (Scarisbrick et al., 1993). Slide-mounted sections were washed in $0.1 \mathrm{M}$ glycine, followed by $0.1 \mathrm{M}$ phosphate buffer, $\mathrm{pH} 7.2$, and then incubated in $1 \mu \mathrm{g} / \mathrm{ml}$ proteinase $\mathrm{K}, 50 \mathrm{~mm}$ EDTA, and $0.1 \mathrm{~m}$ Tris- $\mathrm{Cl}, \mathrm{pH} 8$, for $30 \mathrm{~min}$ at $37^{\circ} \mathrm{C} ; 0.25 \%$ acetic anhydride in $0.1 \mathrm{M}$ triethanolamine, $\mathrm{pH} 8.0$, for $10 \mathrm{~min}$ at room temperature; and finally washed in $2 \times$ SSC for $1 \mathrm{hr}$. The sections were defatted in chloroform and air-dried before application of the hybridization buffer containing $1 \times$ $10^{6} \mathrm{cpm} / 100 \mu \mathrm{l}$ of the $\left[\alpha-{ }^{35} \mathrm{~S}\right]-$ UTP-labeled cRNA. The hybridization buffer containing $50 \%$ deionized formamide, $10 \%$ dextran sulfate, $0.7 \%$ Ficoll, $0.7 \%$ polyvinyl pyrrolidone, $0.7 \%$ bovine serum albumin, 0.15 $\mathrm{mg} / \mathrm{ml}$ yeast tRNA, $0.33 \mathrm{mg} / \mathrm{ml}$ denatured herring sperm DNA, and 40 $\mu \mathrm{M}$ dithiothreitol (DTT) was applied to air-dried sections. Slides were coverslipped and incubated for $36 \mathrm{hr}$ at $60^{\circ} \mathrm{C}$ in a humidified chamber. The hybridized sections were washed in $4 \times \mathrm{SSC}$ buffer, $\mathrm{pH} 7.0$, containing $6.4 \mathrm{~mm}$ sodium thiosulfate and treated with $20 \mu \mathrm{g} / \mathrm{ml}$ ribonuclease A in $10 \mathrm{~mm}$ Tris-Cl and $1 \mathrm{~mm}$ EDTA, $\mathrm{pH} 8$, for $30 \mathrm{~min}$ at $45^{\circ} \mathrm{C}$. Over the next $18 \mathrm{hr}$ sections were washed in sodium thiosulfate containing SSC solutions of increasing stringency. This included two $30 \mathrm{~min}$ incubations in $0.5 \times$ and $0.1 \times \mathrm{SSC}$ at $60^{\circ} \mathrm{C}$ and a final wash in $0.1 \times \mathrm{SSC}$ at room temperature overnight. Air-dried sections of control and KA-treated spinal cords, along with a set of radioactive standards $\left(\mathrm{C}^{14}\right.$, Amersham), then were applied to $\beta$-Max x-ray film and exposed for $4-7 \mathrm{~d}$. After development of the film, the slide-mounted sections were defatted further in chloroform, coated with Kodak NTB2 emulsion (1:1 with $\mathrm{H}_{2} 0$; Eastman Kodak), exposed for $10 \mathrm{~d}$ at $4^{\circ} \mathrm{C}$, developed in Kodak D19, fixed, and stained with $0.25 \%$ cresyl violet.

Densitometric quantitation of $r M S P$ mRNA. The relative distribution of rMSP mRNA in the white and gray layers of the spinal cord and changes 
in the expression of rMSP mRNA after KA administration were quantified by comparison of ROD measurements of densitometer-scanned film autoradiographs (Microcomputer Imaging Device, Imaging Research, St. Catherines, Ontario). Densitometric measurements were taken from the spinal cord white matter and the dorsal and ventral gray regions of control and $\mathrm{KA}$-treated animals processed in parallel. The ROD of film autoradiographs was calibrated to film images of $\mathrm{C}^{14}$ standards (Amersham). The mean labeling density in individual cases was calculated by measuring the ROD of no fewer than 30 samples of at least 10 tissue sections. The significance of changes in MSP mRNA hybridization at different time points was determined via a comparison of the percentage of labeling observed in experimental tissue sections compared with control tissue sections hybridized in parallel. The statistical significance of KA-induced changes in rMSP cRNA labeling was evaluated by one-way ANOVA of the mean percentage of control of at least four animals at each time point, followed by the Student-NewmanKeuls post hoc test for paired comparisons. Differences were considered significant when $p$ was $<0.05$ and expressed as mean $\pm \mathrm{SE}$.

\section{Immunohistochemistry}

The oligodendroglial or astrocytic identity of MSP mRNA-expressing spinal cord glia was characterized by immunostaining of adjacent sections through the normal lumbosacral spinal cord for glial-specific antigens. The distribution of oligodendroglia was determined by localization of 2', 3'-cyclic nucleotide $3^{\prime}$-phosphodiesterase (CNPase), an enzyme uniquely localized to myelin-producing cells such as oligodendrocytes (Prineas et al., 1989; Reynolds et al., 1989; Scherer et al., 1994; Barradas et al., 1995), with a mouse monoclonal antibody anti-CNPase (Clone 11-5B, Sigma). The distribution of astrocytes was determined by localization of glial fibrillary acidic protein (GFAP, mouse monoclonal, Clone G-A-5; Sigma). Primary antibodies were diluted in $0.1 \mathrm{M}$ phosphate buffer containing $0.25 \%$ Triton $\mathrm{X}-100$ and $3 \%$ normal swine serum at a ratio of 1:500. Free-floating sections were incubated in the anti-CNPase or the anti-GFAP primary antisera at $4^{\circ} \mathrm{C}$ for $24 \mathrm{hr}$. Then sections were washed in cold $0.1 \mathrm{M}$ phosphate buffer and incubated in biotinylated anti-mouse secondary immunoglobulins (Vector Laboratories), diluted in the same solution as the primaries at 1:200, for $1 \mathrm{hr}$ at room temperature. After being washed in cold $0.1 \mathrm{M}$ phosphate buffer, the sections were reacted further with the avidin-biotin peroxidase technique (Vectastain, Vector Laboratories, Burlingame, CA), and the immunostaining was visualized with a metal-enhanced diaminobenzidine (DAB) substrate (Pierce, Rockford, IL). The DAB reaction was stopped by washing the sections in $0.1 \mathrm{M}$ phosphate buffer before the sections were mounted onto $0.5 \%$ gelatin-coated slides, dehydrated, cleared, and coverslipped.

\section{RESULTS}

\section{Human and rat MSP clone and sequence analysis}

To identify serine proteases potentially important in the normal and injured spinal cord, we have used PCR amplification with degenerate oligonucleotide primers designed on the basis of regions of homology between known serine proteases. One of the cDNA clones isolated in this manner was found to encode a previously unidentified member of the trypsin/chymotrypsin serine protease family. Sequence analysis of a fulllength cDNA clone predicted an amino acid sequence of 251 residues for the precursor of this protease, designated MSP (Fig. 1; GenBank accession number AF016269). MSP is most similar in sequence to neuropsin (48\% amino acid sequence identity), trypsin (45\%), and tissue kallikrein (36\%) (Fig. 2). MSP is 34\% identical to mouse tPA within the coding region of the serine protease domain (Rickles et al., 1988). Amino acid residues comprising the active site catalytic triad, His 57, Asp 102, and Ser 195, are all conserved in MSP. The conservation of key residues surrounding the substrate binding pocket (Asp 189, Gly 216, and Gly 226) suggests that MSP has trypsin-like activity (Shotton and Watson, 1970).

\section{Regional expression of MSP}

The distribution of mRNA encoding the serine proteases MSP and tPA has been determined in neural and non-neural tissues of the rat with ${ }^{32} \mathrm{P}$-labeled cDNA probes and Northern blot techniques. These experiments have shown that, in the rat, MSP mRNA is more abundant in the CNS, as compared with the peripheral tissues examined (Fig. $3 A$ ). Relative to RNA samples from whole rat brain, $\sim 10$-fold lower levels of MSP mRNA were observed in the lung, and lower levels still were observed in the spleen, liver, skeletal muscle, kidney, and testes of the rat. By contrast to MSP, tPA mRNA was observed at a more uniform level in RNA samples of different tissues examined, including heart, brain, lung, kidney, and skeletal muscle (Fig. 3B). The cyclophilin (Fig. 3C), $\beta$-actin (Fig. 3D), and the GAPDH (data not shown) cDNA control probes hybridized to the same blot were not found to be distributed equally among the RNA samples of brain and peripheral tissues examined, although together they demonstrated adequate loading of RNA.

The relative distribution of MSP and IPA mRNA in the human CNS and peripheral tissues has been examined by probing a multiple tissue Northern dot blot containing poly $\left(\mathrm{A}^{+}\right)$RNA from 15 different adult human brain regions and 28 peripheral tissues, with a ${ }^{32} \mathrm{P}$-labeled CD2 cDNA probe (Fig. 4). Of all the brain regions contained on this blot, MSP cDNA hybridization was the most dense in the spinal cord and medulla oblongata, where similar levels were detected, with lower levels in other brain regions and in most other peripheral tissues that were examined. To judge the relative abundance of MSP in each RNA sample, we compared levels of cDNA hybridization directly with the highest levels observed, that is those in the spinal cord, and expressed them as a percentage in Table 1. Mirroring the distribution of MSP mRNA observed in mRNA extracts from whole adult rat brain compared with spinal cord (Fig. 5A), MSP mRNA levels in the RNA samples of whole adult human brain were 6-fold lower relative to the RNA samples of the spinal cord and medulla oblongata (see Fig. 4, Table 1). The next highest levels of MSP cDNA hybridization in the human brain were observed in the hippocampus, frontal lobe, thalamus, subthalamic nuclei, and the substantia nigra, in which the level of hybridization was $\sim 2-$ to 3 -fold lower than that observed in the spinal cord. MSP mRNA levels in the putamen, cerebral cortex, caudate nucleus, amygdala, and temporal lobe were 4- to 7-fold lower than in the spinal cord. The lowest levels of MSP mRNA were detected in the occipital pole and cerebellum, where levels were $\sim 12$-fold lower than those detected in the spinal cord. The level of MSP mRNA in these brain regions was found to be equal to, or lower than, the level detected in most peripheral tissues. The highest levels of MSP cDNA hybridization in human peripheral tissues occurred in the kidney, where levels were only slightly lower than those observed in the spinal cord. The next highest levels of MSP mRNA in the peripheral tissues examined were observed in the lung, thymus, thyroid gland, ovary, and mammary gland, where levels were $\sim 5$ to 6-fold lower than that detected in the spinal cord. Among the lowest levels of MSP mRNA were those detected in muscle of cardiac, aortic, or skeletal muscle cell origin, where levels were 10 - to 20 -fold lower than that observed in the spinal cord. Elsewhere in peripheral tissues the level of MSP mRNA detected was similar to the level observed in the cerebellum of the brain, that is $\sim 7$ - to 10 -fold lower than that observed in the spinal cord.

Both similarities and differences were observed in the distribution of tPA mRNA relative to that of MSP in the human brain regions and peripheral tissues examined (Fig. 4). The highest levels of tPA, like those of MSP in the human brain, were detected in the spinal cord. By contrast to MSP, tPA mRNA was found to be distributed more uniformly across the other brain regions exam- 


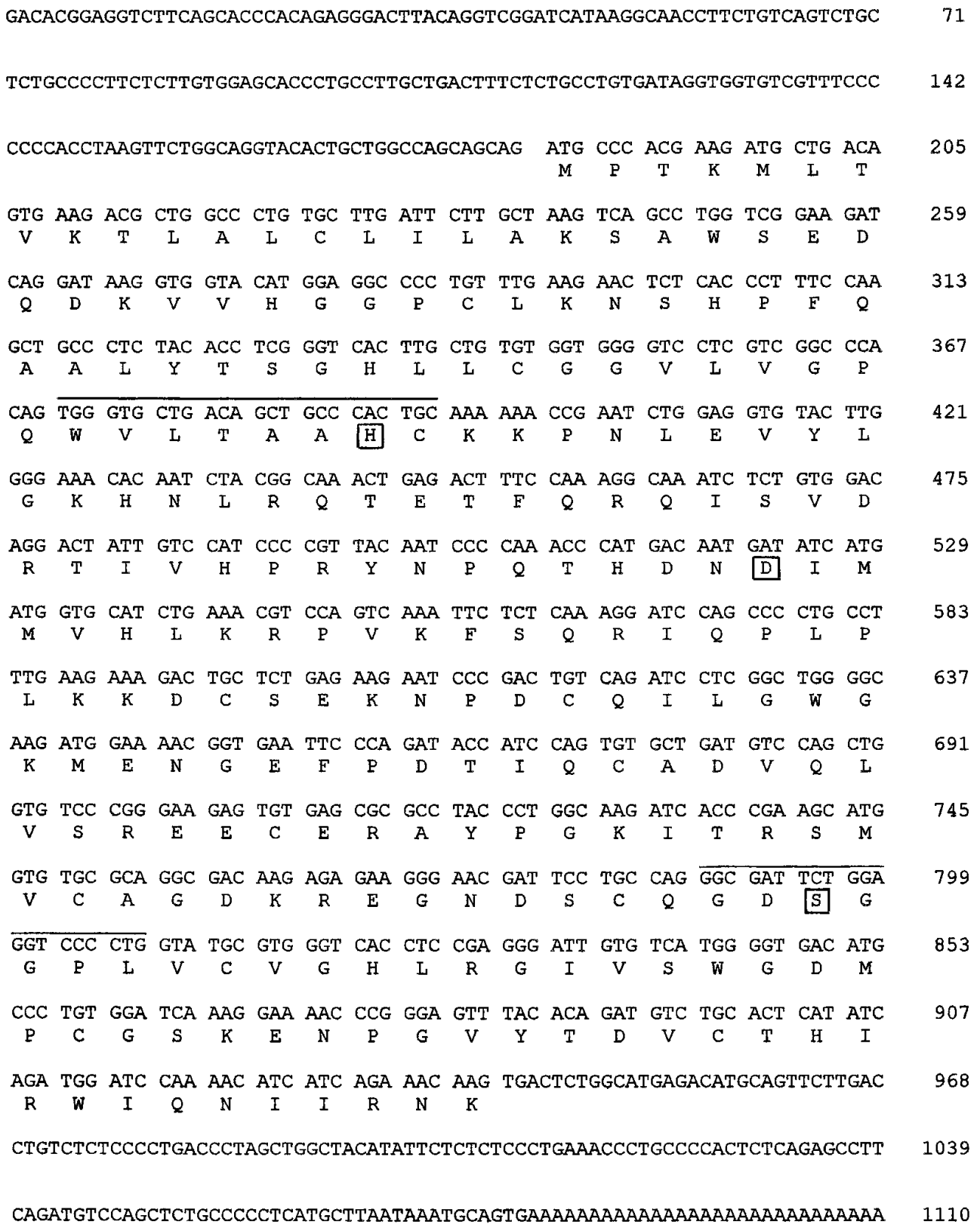

Figure 1. Nucleotide and deduced amino acid sequences of rat MSP cDNA. The primers for the initial PCR amplification are indicated by lines. Amino acid residues corresponding to the conserved residues of the catalytic triad are boxed.

ined, including the medulla oblongata, and only 2- to 2.5 -fold lower than the level of tPA mRNA observed in the spinal cord (Table 1). Also in contrast to MSP, tPA mRNA was widely and densely distributed in the peripheral tissues contained on this blot. Indeed, the levels of tPA mRNA in the human kidney, adrenal gland, colon, bladder, uterus, stomach, and small intestine were all greater than the level detected in the spinal cord, whereas those in the heart, aorta, pancreas, thyroid gland, and liver were similar to those observed in the spinal cord. Significant levels of tPA mRNA were observed in each of the other tissues examined, including skeletal muscle, where levels were from 1.5- to 2.5-fold lower than in the spinal cord. Interestingly, the highest levels of tPA mRNA in the human peripheral tissues examined were, like those of MSP mRNA, observed in kidney.

\section{Cell-specific expression of MSP in the adult rat spinal cord}

As shown in Figures 6, 8, and 9, MSP cRNA hybridization in the normal adult rat lumbosacral spinal cord predominates in the white matter glia. MSP cRNA labeling in the gray matter laminae I to $\mathrm{X}$ was widespread but occurred at an overall lower level than that observed in the white matter of control animals (Fig. 6A). The alpha motor neurons of lamina IX in control animals clearly were associated with low levels of MSP cRNA labeling (Figs. $6 A, 8 A, 9 A$ ). By contrast to MSP, tPA cRNA labeling was found to be dense in association with the neurons of the spinal cord gray matter, with only very low levels of labeling in the white matter (our unpublished data). Densitometric measurements of film autoradiographs showed that the 


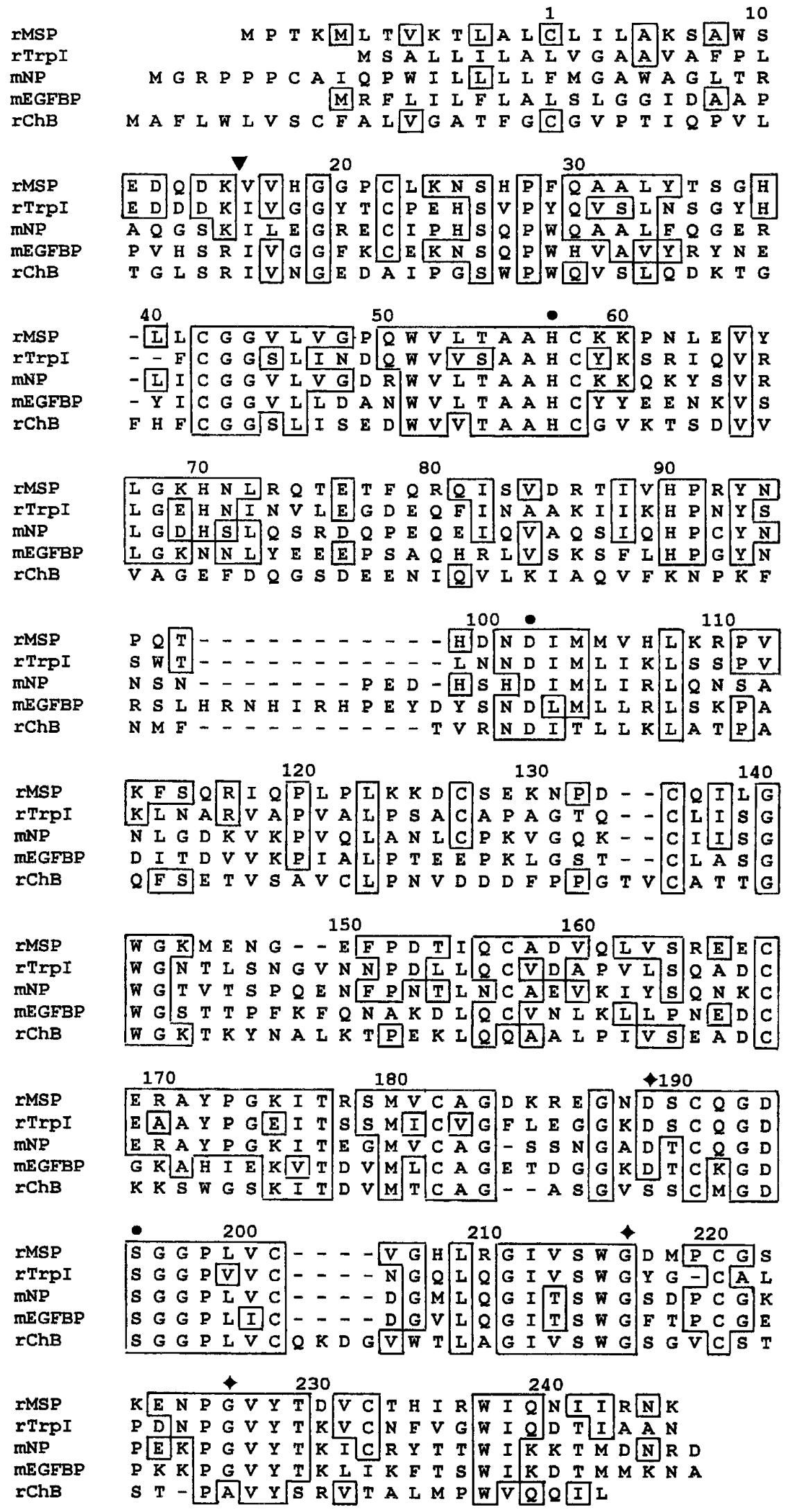

Figure 2. Comparison of the predicted amino acid sequence of MSP and the amino acid sequences of several members of the chymotrypsin serine protease family. Shown is the amino acid sequence comparison of rat myelencephalon-specific protease $(r M S P)$ with rat trypsinogen I $(r T r p I)$ (MacDonald et al., 1982), mouse neuropsin ( $m N P$ ) (Chen et al., 1995), mouse EGF binding protein ( $m E G F B P$ ) (Blaber et al., 1987), and rat chymotrypsinogen B $(r C h B)$ (Bell et al., 1984). MSP is most similar in sequence to neuropsin (48\% amino acid sequence identity) and trypsin (45\%). (Figure legend continues) 

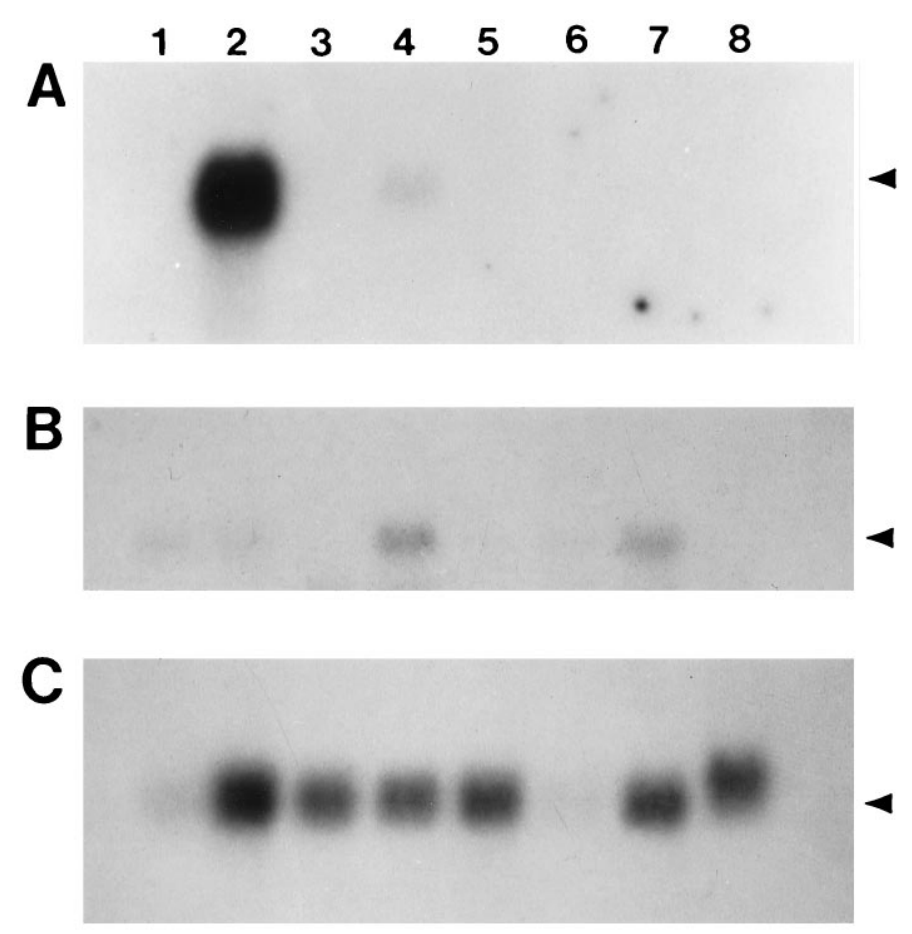

D

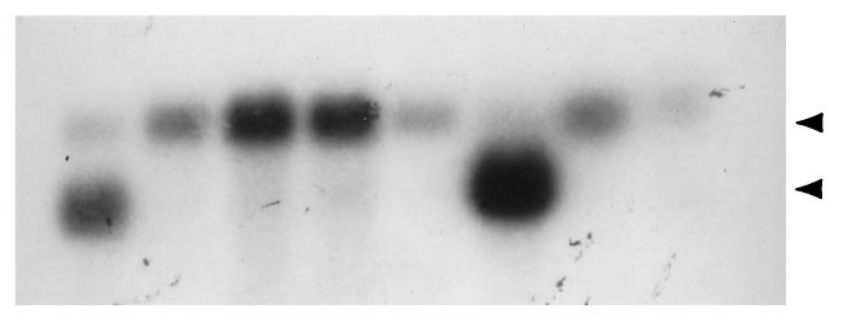

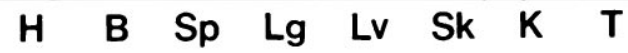

Figure 3. MSP mRNA in the adult rat is expressed at higher levels in the brain than in the peripheral tissues that were examined. Shown are film autoradiographs of a Northern blot containing samples of total RNA from whole brain (including spinal cord) and seven different peripheral tissues hybridized with a ${ }^{32} \mathrm{P}$-labeled cDNA probe of rat MSP (pM444-4; $A$ ), tPA $(\mathrm{pM} 455 ; B)$, cyclophilin $(C)$, or $\beta$-actin $(D)$. Each lane contains $2 \mu \mathrm{g}$ of poly $\left(\mathrm{A}^{+}\right)$RNA isolated from the heart $(H)$, brain $(B)$, spleen $(S p)$, lung $(L g)$, liver $(L v)$, skeletal muscle $(S k)$, kidney $(K)$, and testes $(T)$ of adult rats. rMSP cDNA hybridization produced a single band (arrowhead, $A$ ), and was $\sim 10$-fold greater in RNA samples of whole brain relative to RNA samples of peripheral tissues contained on this blot. By contrast to MSP, tPA mRNA (arrowhead, B) was more widespread in peripheral tissues. Hybridization of the cyclophilin (arrowhead, $C$ ) and $\beta$-actin (arrowheads, $D)$ control cDNA probes to the same blot showed adequate loading of RNA but unequal amounts of the mRNA encoding each in brain relative to peripheral tissues. Notably, cyclophilin mRNA was low in samples from heart or skeletal muscle $(C)$. The two bands corresponding to the 1.8 and $2.0 \mathrm{~kb}$ isoforms of $\beta$-actin were observed in heart and skeletal muscle $(D)$.

density of MSP cRNA labeling was 2-fold higher in the spinal cord white matter, as compared with the gray matter of control animals $(p<0.001$, Student-Newman-Keuls; data not shown). There were no significant differences in MSP cRNA labeling density between the dorsal and ventral regions of spinal cord gray matter in control animals.

White matter glia associated with dense-to-light MSP cRNA labeling formed a subpopulation of the total, such that they were distinct from other glia in which no MSP cRNA labeling was observed (Fig. 8C,D). In sagittal section, white matter glia associated with high levels of MSP mRNA hybridization were arranged in a linear manner, paralleling the course of major fiber tracts (data not shown). Among the cells hybridizing the highest levels of MSP cRNA in the gray matter was a sparsely distributed population, with small darkly Nissl-stained nuclei, of similar size and labeling intensity to the white matter glia (Figs. $8 A, B, 9 A, B$ ). The identity of MSP-producing glia was characterized further by examination of the distribution of CNPase-immunoreactive oligodendroglia and GFAP-immunoreactive astroglia in parallel sections (Fig. 9C,D). Overall, the appearance of MSP-producing glia resembled that of CNPase-immunoreactive oligodendrocytes, which were abundant in the white matter and sparsely distributed in the gray matter. By contrast, GFAP-immunoreactive astrocytes were abundant in both the white and gray matter of the adult rat spinal cord. Schwann cells of the proximal portions of the dorsal and ventral roots were associated with little MSP cRNA labeling (Fig. 6B,C).

\section{Regulation of MSP mRNA expression by excitotoxic injury}

Northern and in situ RNA analyses demonstrated that MSP mRNA expression increases $\sim 2$-fold in the adult rat spinal cord by $3 \mathrm{~d}$ after intraperitoneal injection of KA (Figs. 5-9). By contrast, at 12 and $24 \mathrm{hr}$ changes in MSP mRNA expression were not significantly different from controls (Fig. 7). Significant increases in MSP mRNA hybridization were first observed by $48 \mathrm{hr}$ after KA injury (data not shown). At $72 \mathrm{hr}$ there was a 3-fold increase in MSP mRNA hybridization in the spinal cord white matter and a coordinate 1.5 -fold increase in the dorsal and ventral horns of the gray matter (Figs. 6-8). The level of MSP mRNA expression in the ventral horn of the spinal cord gray matter remained elevated to 1.5 -fold over control up to 1 week after KA exposure $(p<0.05)$, whereas the levels of expression in the dorsal regions of gray matter and in the spinal cord white matter were no longer significantly different from control animals (Fig. 7).

Increases in MSP mRNA expression occurred within each lamina of the spinal cord gray matter. This increase was particularly evident in association with the motor neurons of lamina IX, in which the levels of MSP cRNA labeling at 3 and $7 \mathrm{~d}$ after KA exposure were similar to the dense level of labeling observed in association with white matter glia of control and KA-treated rats (Figs. 6, 8, 9). The dramatic increase in MSP mRNA expression observed in association with white matter glia at $3 \mathrm{~d}$ after the initial excitotoxic insult was the result of both an increase in hybridization associated with individual cells and in the number of cells associated with signal (Fig. $8 C, D$ ). Similarly, in the spinal gray matter there was an increase in both the number of glial cells associated with MSP cRNA labeling and in the density of signal associated with each (Fig. $8 A, B$ ).

Changes in the level of rMSP mRNA expression after KA 


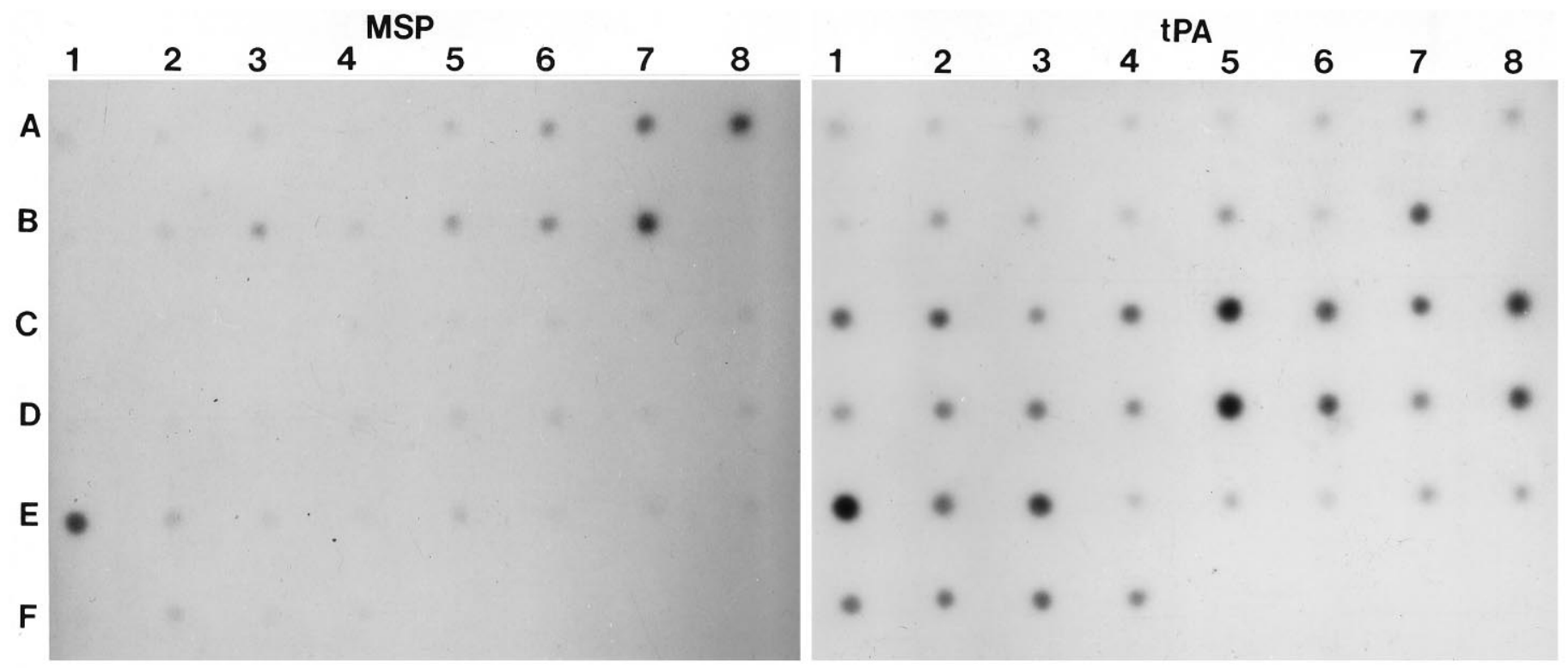

Figure 4. Comparison of the level of MSP and tPA mRNAs in adult human brain and peripheral tissues. Shown are film autoradiograms of hybridization of ${ }^{32} \mathrm{P}$-labeled human MSP and tPA cDNA probes to a human multiple tissue dot blot containing poly $\left(\mathrm{A}^{+}\right)$RNA from 43 different regions, including the brain (rows $A$ and $B$ ) and peripheral tissues (rows $C-F$ ). Densitometric measurements of cDNA hybridization to each sample were compared directly with the level of hybridization observed in the spinal cord and expressed as a percentage in Table 1. This comparison demonstrated that, of all human brain regions examined, MSP mRNA was present at the highest level in the spinal cord (B7) and medulla oblongata $(A 8)$ (see also Fig. 5). Significant levels of MSP mRNA also were observed in the hippocampus (A7), thalamus (B5), subthalamic nuclei (B6), frontal lobe (A6), and substantia nigra (B3). By contrast to this, the level of MSP mRNA hybridized in samples of most peripheral tissues was similar to the low level detected in the amygdala $(A 2)$, cerebellum $(A 4)$, and occipital $(B 1)$ and temporal lobes $(B 4)$ of the brain, where the level of MSP mRNA hybridization was $\sim 5$ to 20 -fold lower than that observed in the spinal cord. The exception to this was the kidney (E1), where the level of MSP mRNA detected was similar to that detected in the spinal cord (B7) and medulla oblongata (A8). Compared with MSP mRNA, tPA mRNA was distributed more uniformly across the brain regions examined but was, like MSP, highest in the spinal cord. In striking contrast to MSP, tPA mRNA was distributed much more widely in peripheral tissues, including skeletal muscle $(C 3)$.

treatment observed by in situ hybridization were confirmed by the results of Northern hybridization of mRNA isolated from control and KA-treated adult rat spinal cords (see Fig. 5). Approximately 1.6-fold higher levels of MSP mRNA were detected in RNA samples of the whole rat spinal cord at $7 \mathrm{~d}$ after KA exposure, as compared with controls (see Fig. 5A). Paralleling the distribution of MSP mRNA in RNA samples of the human spinal cord (see Fig. 4), MSP mRNA levels were found to be $\sim 7$-fold higher in the rat spinal cord, as compared with the whole remainder of the rat CNS. Hybridization of the rat cyclophilin cDNA probe was used to normalize measurements of MSP cDNA hybridization for any variation in the amount of RNA sample loaded.

\section{DISCUSSION}

The present studies were undertaken to determine the potential activity of serine proteases in the adult spinal cord. We have described the cloning of a novel gene encoding a trypsin-like serine protease related to neuropsin and tissue kallikrein. The expression of MSP mRNA in both the rat and human was shown to occur predominantly in the nervous system and to be the most dense in the spinal cord and medulla oblongata. These observations point to the potentially nervous system-specific activity of the novel serine protease described herein, which we have designated myelencephalon-specific protease (MSP). The 2-fold increase in MSP mRNA expression in spinal cord glia and neurons of the adult rat, including alpha motor neurons, by $3 \mathrm{~d}$ after KA/AMPA receptor-mediated excitotoxic injury suggests that the activity of MSP may be involved in proteolytic cascades in the normal and injured adult spinal cord.

\section{MSP substrate specificity}

Although the normal physiological substrates of MSP are not known, the predicted amino acid sequence suggests that the activated protease will have a substrate specificity similar to trypsin and, therefore, a potentially broad range of activity. Relative to other known serine proteases, MSP is small and does not have a large amino terminal domain. The predicted signal peptide identified by sequence analysis suggests that MSP is secreted. Potential functions of secreted proteases include local modification of the extracellular matrix and cleavage of extracellular matrix-associated growth factor precursor proteins (Matrisian and Hogan, 1990; McGuire and Seeds, 1990). The identification of proteases with potential activity in the nervous system, such as MSP, is a critical component to understanding key factors and mechanisms involved in remodeling events associated with synaptic plasticity and cell survival, which participate in the development, normal function, and response of the nervous system to injury.

\section{Region and cell-specific expression of MSP in the CNS}

The activation and proteolytic actions of serine proteases, such as thrombin and the plasminogen activators, are best characterized in peripheral tissues, but considerable evidence points to their expression and activity in the nervous system. For example, plasminogen activators have been shown to be produced and secreted by neurons and glia and to participate in remodeling events that occur during cell migration (Moonen et al., 1982), neurite outgrowth (Monard, 1988; Pittman and Williams, 1989; Sumi et al., 1992; Sappino et al., 1993), and synaptic plasticity (Monard, 1988; Qian et al., 1993; Sappino et al., 1993). MSP 


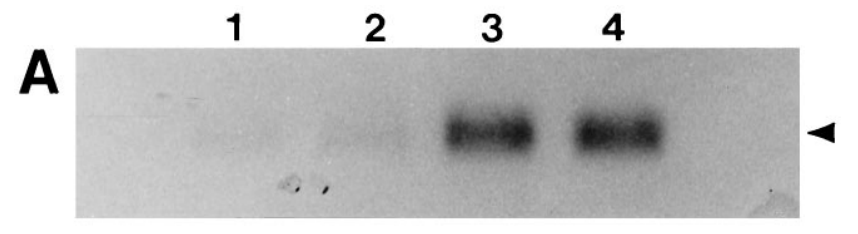

B

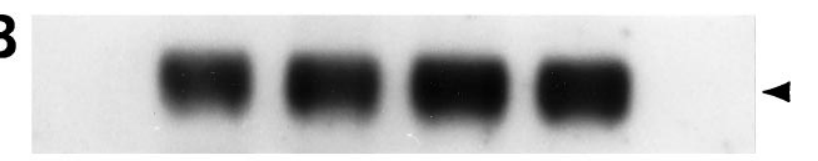

Figure 5. MSP mRNA in whole brain or spinal cord of control and KA-treated adult rats. Shown are film autoradiograms of hybridization of a Northern blot sequentially hybridized with a random primed ${ }^{32} \mathrm{P}-l$ labeled rat MSP (arrowhead, $A$ ) or rat cyclophilin (arrowhead, B) cDNA probe. Lanes contain $1 \mu \mathrm{g}$ of mRNA isolated from samples of whole brain (lanes 1 and 2) or spinal cord (lanes 3 and 4 ) of control adult rats (lanes 1 and 3 ) or from rats at $7 \mathrm{~d}$ after intraperitoneal administration of KA (lanes 2 and 4 ). The amount of rMSP mRNA detected in different samples was normalized to the amount of mRNA loaded by rehybridizing the membrane to a rat cyclophilin cDNA probe. In control adult rats, MSP mRNA was more than 7-fold more abundant in mRNA samples of the spinal cord (lane 3), as compared with mRNA from samples of homogenized whole rat brain (lane 1; see also Fig. 4). A 2-fold increase in rMSP mRNA was observed in mRNA samples of spinal cord $7 \mathrm{~d}$ after administration of KA (lane 4), as compared with controls (lane 3). A parallel increase in MSP mRNA expression was observed by quantification of the amount of MSP cRNA labeling by in situ hybridization histochemistry (see Fig. 7).

expression was observed in peripheral tissues but, except for kidney, was $\sim 5$ - to 20 -fold lower than levels detected in the brain and spinal cord. MSP mRNA expression was detected in each brain region examined, including the hippocampus, substantia nigra, and cerebral cortex, but the highest levels of expression, by at least 2-fold, were detected in the spinal cord and medulla oblongata. Within the adult rat spinal cord, MSP mRNA was found to be associated with neurons throughout the dorsal and ventral regions of gray matter and to be abundant in a select population of white matter glia. Thus, although MSP is likely to have a broad range of substrate specificity, its action is regulated in part by tissue- and cell-specific expression patterns.

The evidence showing activity of tPA in neuronal survival and plasticity-related events (Qian et al., 1993; Carroll et al., 1994; Seeds et al., 1995; Frey et al., 1996) prompted us to compare its expression with that of MSP. tPA mRNA has been shown previously to be widespread in the brain of adult rodents (Sappino et al., 1993; Ware et al., 1995), and our observations extend this view to the human brain. Additionally, we have found that tPA mRNA, like MSP, is elevated in the spinal cord relative to all other regions of the human brain examined. Despite the similarities in distribution in the spinal cord, tPA mRNA was, by contrast, distributed more uniformly in the other brain regions examined and far more widespread in peripheral tissues. The dense expression of both MSP and tPA in the spinal cord points to their role in maintaining the integrity of the normal spinal cord and potentially in the pathogenesis of certain spinal cord-related disease states, such as amyotrophic lateral sclerosis.

The most striking feature of the cellular localization of MSP in the spinal cord was the dense expression by white matter glia. A number of roles for glial-produced serine proteases and protease inhibitors have been demonstrated. For example, astrocytederived PNI enhances the survival of mixed spinal neuron cultures (Festoff et al., 1996). Thrombin has been shown to induce

\begin{tabular}{|c|c|c|c|}
\hline & RNA source & MSP & tPA \\
\hline A1 & Whole brain & 18 & 55 \\
\hline A 2 & Amygdala & 15 & 46 \\
\hline A3 & Caudate nucleus & 19 & 57 \\
\hline A4 & Cerebellum & 8 & 46 \\
\hline A5 & Cerebral cortex & 20 & 40 \\
\hline A6 & Frontal lobe & 43 & 51 \\
\hline A7 & Hippocampus & 57 & 62 \\
\hline A8 & Medulla oblongata & 102 & 64 \\
\hline B1 & Occipital pole & 9 & 39 \\
\hline B2 & Putamen & 21 & 61 \\
\hline B3 & Substantia nigra & 33 & 46 \\
\hline B4 & Temporal lobe & 13 & 46 \\
\hline B5 & Thalamus & 29 & 76 \\
\hline B6 & Subthalamic nucleus & 34 & 56 \\
\hline B7 & Spinal cord & 100 & 100 \\
\hline $\mathrm{C} 1$ & Heart & 7 & 100 \\
\hline $\mathrm{C} 2$ & Aorta & 5 & 100 \\
\hline $\mathrm{C} 3$ & Skeletal muscle & 9 & 67 \\
\hline $\mathrm{C} 4$ & Colon & 12 & 110 \\
\hline $\mathrm{C} 5$ & Bladder & 12 & 160 \\
\hline C6 & Uterus & 13 & 120 \\
\hline $\mathrm{C} 7$ & Prostate & 13 & 87 \\
\hline $\mathrm{C} 8$ & Stomach & 16 & 140 \\
\hline D1 & Testis & 13 & 71 \\
\hline D2 & Ovary & 9 & 71 \\
\hline D3 & Pancreas & 9 & 91 \\
\hline D4 & Pituitary gland & 16 & 77 \\
\hline D5 & Adrenal gland & 16 & 180 \\
\hline D6 & Thyroid gland & 19 & 110 \\
\hline D7 & Salivary gland & 14 & 75 \\
\hline D8 & Mammary gland & 17 & 120 \\
\hline E1 & Kidney & 87 & 200 \\
\hline E2 & Liver & 23 & 100 \\
\hline E3 & Small intestine & 15 & 130 \\
\hline E4 & Spleen & 9 & 45 \\
\hline E5 & Thymus & 23 & 50 \\
\hline E6 & Peripheral leukocyte & 14 & 40 \\
\hline E7 & Lymph node & 17 & 55 \\
\hline E8 & Bone marrow & 15 & 56 \\
\hline F1 & Appendix & 9 & 83 \\
\hline $\mathrm{F} 2$ & Lung & 20 & 83 \\
\hline F3 & Trachea & 9 & 91 \\
\hline $\mathrm{F} 4$ & Placenta & 9 & 78 \\
\hline
\end{tabular}

The ROD produced by hybridization of ${ }^{32} \mathrm{P}$-labeled hMSP or htPA cDNA probes to each RNA sample contained on the dot blot in Figure 4 was measured and is expressed as a percentage of the signal produced by each cDNA probe after hybridization to RNA samples of the spinal cord (Fig. 4, B7).

the secretion of NGF from cultured astrocytes (Neveu et al., 1993) and to affect their proliferation and differentiation (Cavanaugh et al., 1990; Beecher et al., 1994). We have shown that, within the normal adult rat spinal cord white and gray matter, MSP mRNA expression includes a subpopulation of glia, which are most numerous in the white matter. The abundance of MSPproducing cells in the white matter, but not the gray matter, and their overlap with the distribution of CNPase-immunoreactive oligodendrocytes suggests that MSP mRNA is expressed predominantly by oligodendroglia of the normal adult rat spinal cord. 

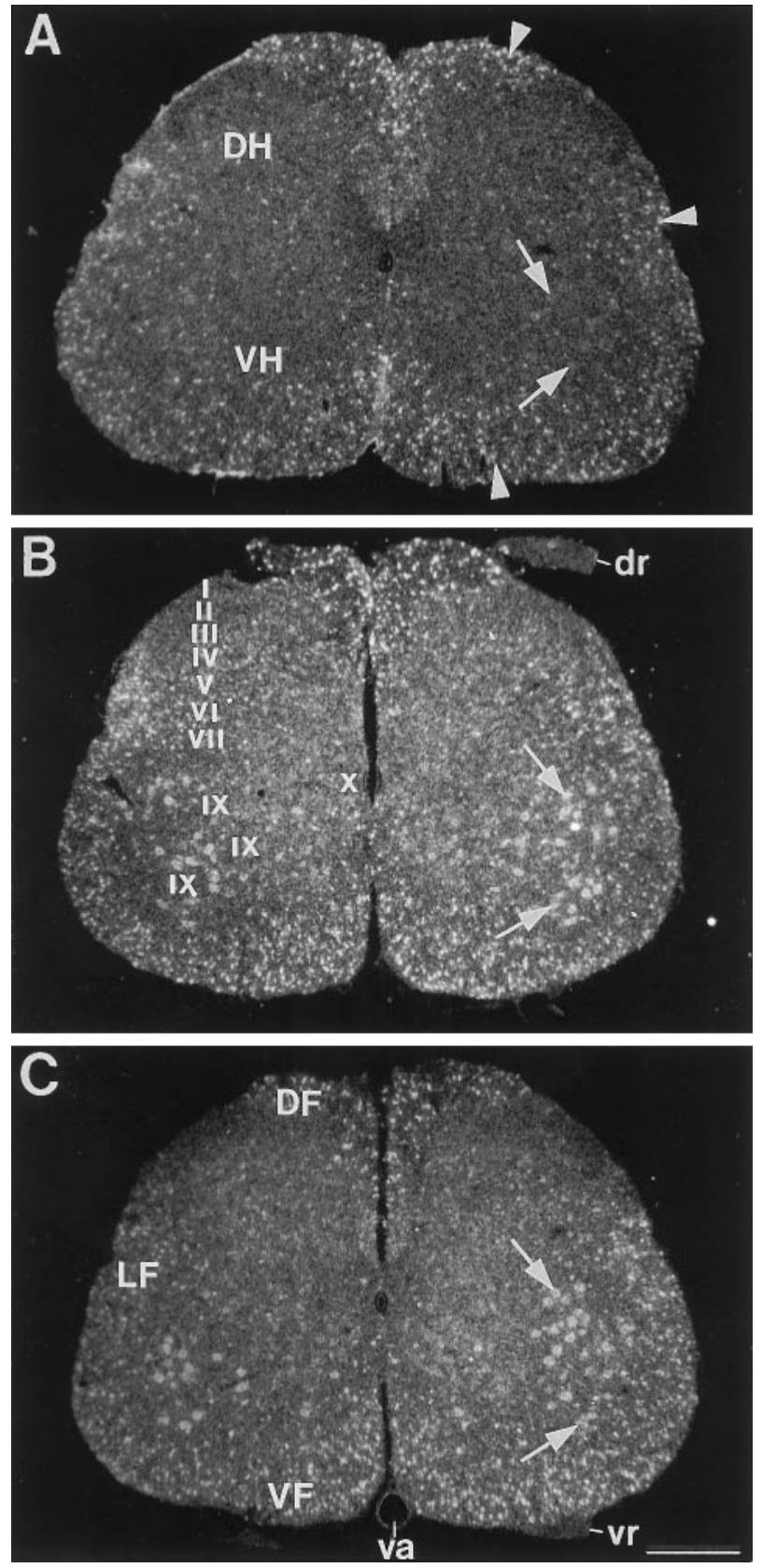

Figure 6. MSP mRNA expression in the adult rat spinal cord increases in the gray and white matter after kainic acid-induced excitotoxic injury. Darkfield photomicrographs show the autoradiographic localization of MSP cRNA hybridization in a transverse section through the lumbosacral spinal cord of a control rat $(A)$ and in parallel sections of paired experimental rats at $3 \mathrm{~d}(B)$ and $7 \mathrm{~d}(C)$ after intraperitoneal administration of KA. The highest levels of MSP cRNA labeling in control sections occurred in association with the white matter glia (arrowheads) throughout the dorsal $(D F)$ lateral $(L F)$, and ventral funiculi $(V F)$. Lower levels of MSP cRNA labeling were associated with neurons in laminae $I-X$ of the spinal cord gray matter of control animals, including the motor neurons of lamina $I X$ (arrows in $A$; see also Fig. 8). By $3 \mathrm{~d}$ after KA administration ( $B)$, MSP mRNA hybridization was 2-fold higher in the white matter and 1.5-fold higher in the dorsal $(\mathrm{DH})$ and ventral $(V H)$ horns of the spinal cord gray matter, as compared with controls (see Fig. 7). Motor neurons of lamina $I X$ of the spinal cord were among the gray matter neurons associated with increased levels of MSP cRNA labeling at 3 and $7 \mathrm{~d}$ after KA administration (arrows in $B$ and $C$ ). The Schwann cells of the proximal portions of the dorsal $(d r)$ or ventral roots $(v r)$ were associated with little MSP mRNA hybridization $(B, C)$. The ventral spinal artery ( $v a$ in $C$ ) and other blood vessels were not associated with MSP mRNA hybridization. Scale bar, $500 \mu \mathrm{m}$.

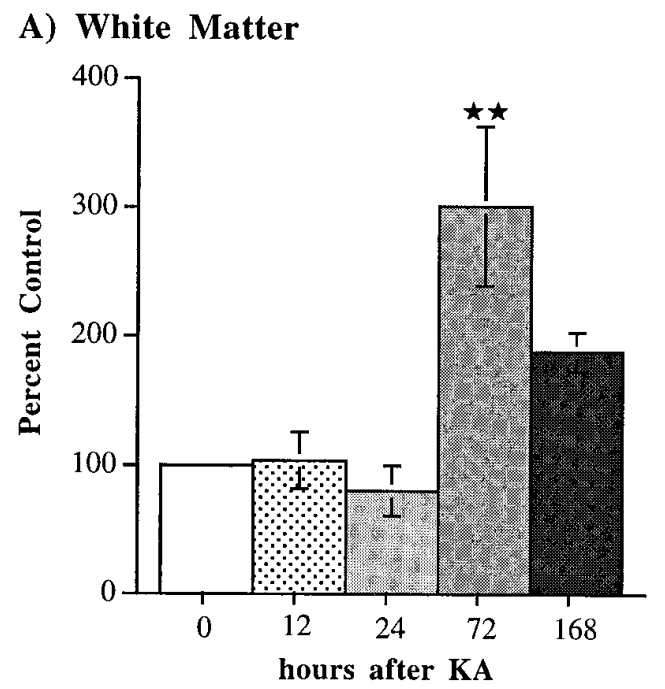

B) Dorsal Gray Matter

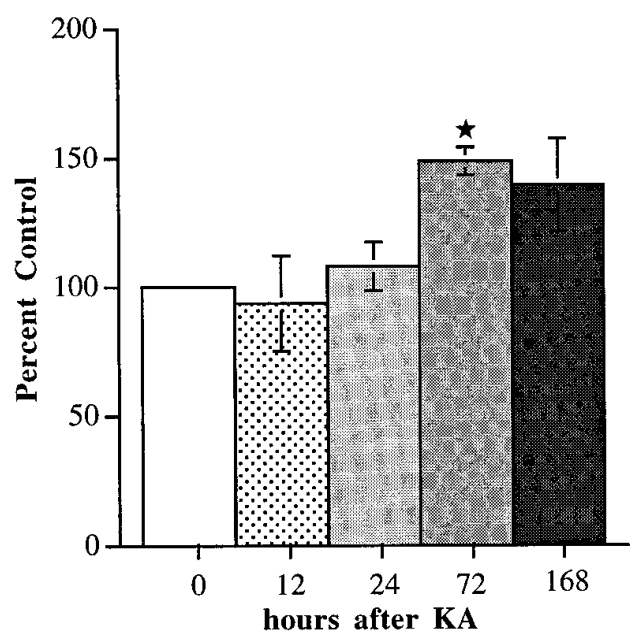

\section{C) Ventral Gray Matter}

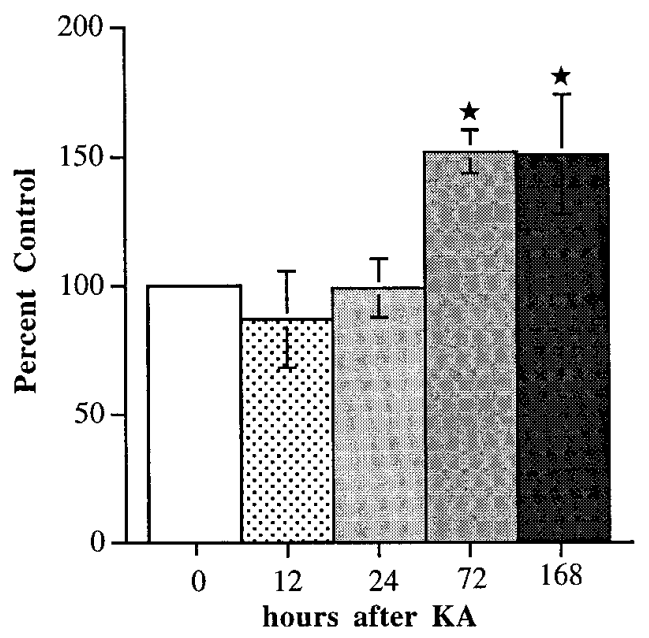

Figure 7. Quantification of kainic acid-induced changes in the expression of MSP mRNA in the white and gray matter of the adult rat lumbosacral spinal cord using in situ hybridization techniques. Bar graphs show densitometric measurements of film autoradiograms of $\alpha-\left[{ }^{35} \mathrm{~S}\right]$-MSP cRNA labeling in the white matter $(A)$ and dorsal $(B)$ (Figure legend continues) 

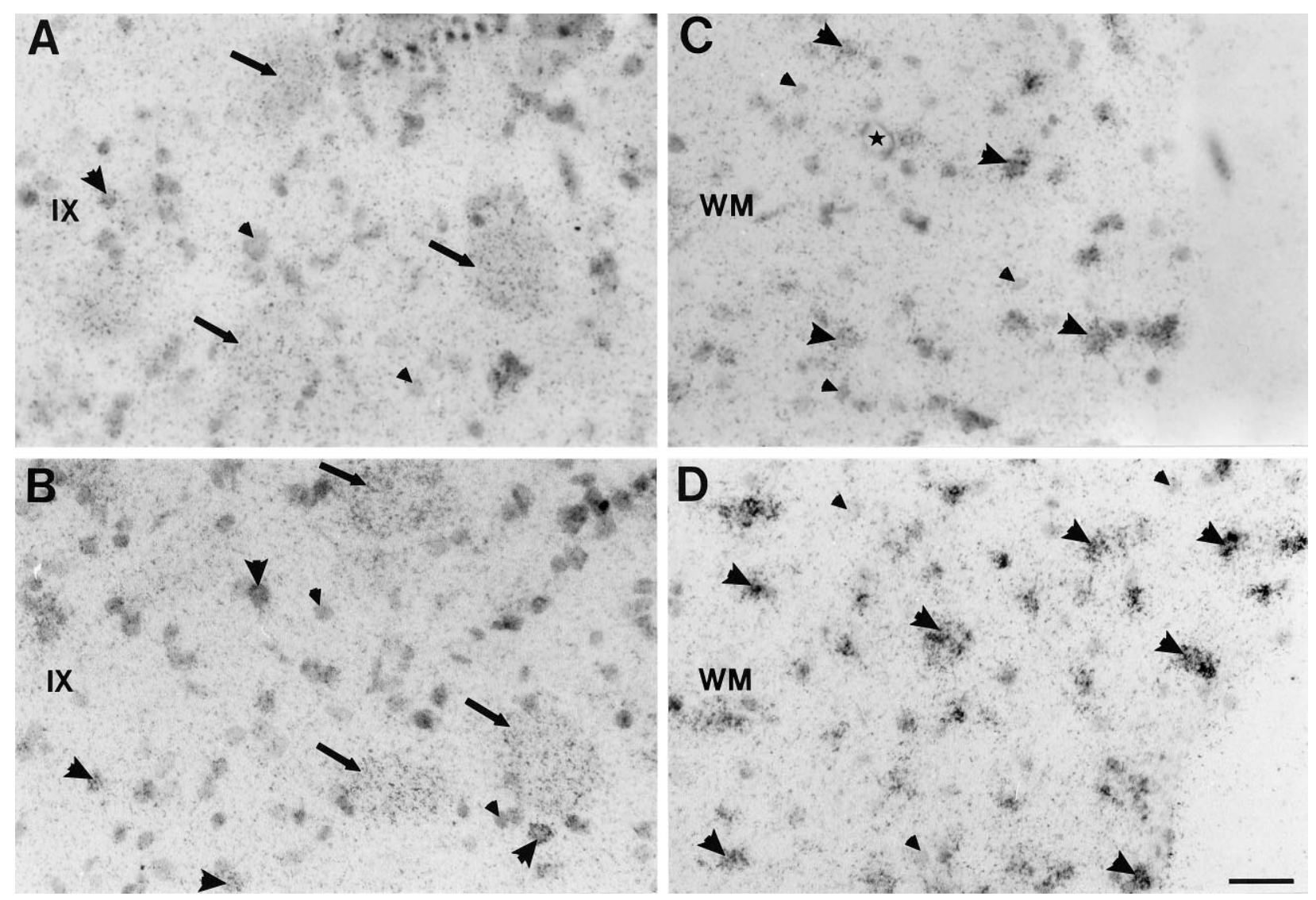

Figure 8. The peak increase in MSP mRNA expression occurred in spinal cord neurons and glia at $72 \mathrm{hr}$ after kainic acid administration. Bright-field photomicrographs show the autoradiographic localization of MSP cRNA labeling seen in the white matter $(W M)$ and lamina $I X$ of the lumbosacral spinal cord of control animals $(A, C)$ and in the same regions in parallel sections of animals at $72 \mathrm{hr}$ after KA-mediated injury $(B, D)$. White matter glia hybridizing MSP cRNA at $72 \mathrm{hr}(D)$ are more numerous and express higher levels of hybridization, as compared with controls (large arrowheads, $C$ ). There is a subpopulation of glia that do not hybridize MSP cRNA in control animals or at $72 \mathrm{hr}$ after KA administration (small arrowheads, A-D). Densitometric measurements of cRNA labeling (see Fig. 7) demonstrated that MSP cRNA hybridization increases 1.5-fold in the ventral horn of the gray matter at $72 \mathrm{hr}$ after KA administration, and this increase is reflected in the relative density of silver grains localized to the alpha motor neurons (arrows) and gray matter glia (large arrowheads) of the ventral horn at $72 \mathrm{hr}$ after KA-exposure $(B)$, as compared with controls $(A)$. Small blood vessels in the substance of the spinal cord are unlabeled with MSP cRNA (star in $C$ ). Scale bar, $25 \mu \mathrm{m}$.

Because protease activity has been shown to influence neurite outgrowth, it is of interest that, whereas astrocytes provide a good substrate for neurite outgrowth in vitro, growth cone collapse is observed with oligodendrocyte contact (Lindsay, 1979; Hatten et al., 1984; Cadelli et al., 1992). Our results also indicate that MSP is not produced at high levels by Schwann cells, at least those of the proximal portions of peripheral nerves, which are known to provide an environment favorable to axon regeneration of both central and peripheral neurons (David and Aguayo, 1981).

\footnotetext{
$\leftarrow$

and ventral gray $(C)$ regions of the lumbosacral spinal cord of rats who were killed at 12, 24, $72(3 \mathrm{~d})$, or $168(7 \mathrm{~d}) \mathrm{hr}$ after intraperitoneal injection of $10 \mathrm{mg} / \mathrm{kg} \mathrm{KA}$. Measurements in each region from KA-treated tissue were expressed as a percentage of values from paired control animals. The values plotted represent group mean \pm SE for $n=4$ per group. Significant differences between treated and control groups were shown by ANOVA $(p<0.01)$. At $72 \mathrm{hr}$ after KA exposure there was a 3 -fold increase in hybridization density in the white matter $(p<0.01)$ and a coordinate 1.5 -fold increase in the dorsal and ventral horns of the spinal cord gray matter $(p<0.05)$. Rat MSP mRNA expression remained significantly increased over controls in the ventral gray matter at $168 \mathrm{hr}$ after KA administration $(p<0.05)$. Stars indicate significant differences from control values $(\star, p<0.05 ; \star \star, p<0.01$; Student-Newman-Keuls post hoc test).
}

Functionally important proteases and their inhibitors regulating plasticity, regeneration, and cell death in the spinal cord remain to be fully characterized. Plasminogen activator activity is present in skeletal muscle and increases both within skeletal muscle (Festoff et al., 1986; Hantai et al., 1990) and facial motor neurons (Nakajima et al., 1996) after axotomy and has been shown to be elevated in muscle of the wobbler mutant mouse (Blondet et al., 1992). The serine protease inhibitor PNI also is produced by skeletal muscle cells, is localized to the neuromuscular synapse (Rao et al., 1985; Festoff et al., 1991), and is upregulated in the distal nerve stump after axotomy (Meier et al., 1989). Importantly, exogenous PNI has been shown to prevent programmed cell death in the motor cell column of the developing chick and axotomy-induced motor neuron degeneration in the neonatal mouse (Houenou et al., 1995). Within the alpha motor neuron-muscle cell axis we show that MSP mRNA expression predominates in motor neurons, whereas by comparison there is little detectable expression in skeletal muscle of the adult rat or human. By contrast to MSP, tPA mRNA was detected at significant levels in skeletal muscle as well as in the spinal cord. The selective production of MSP mRNA by spinal motor neurons and the possibility of anterograde transport and axonal release of MSP 

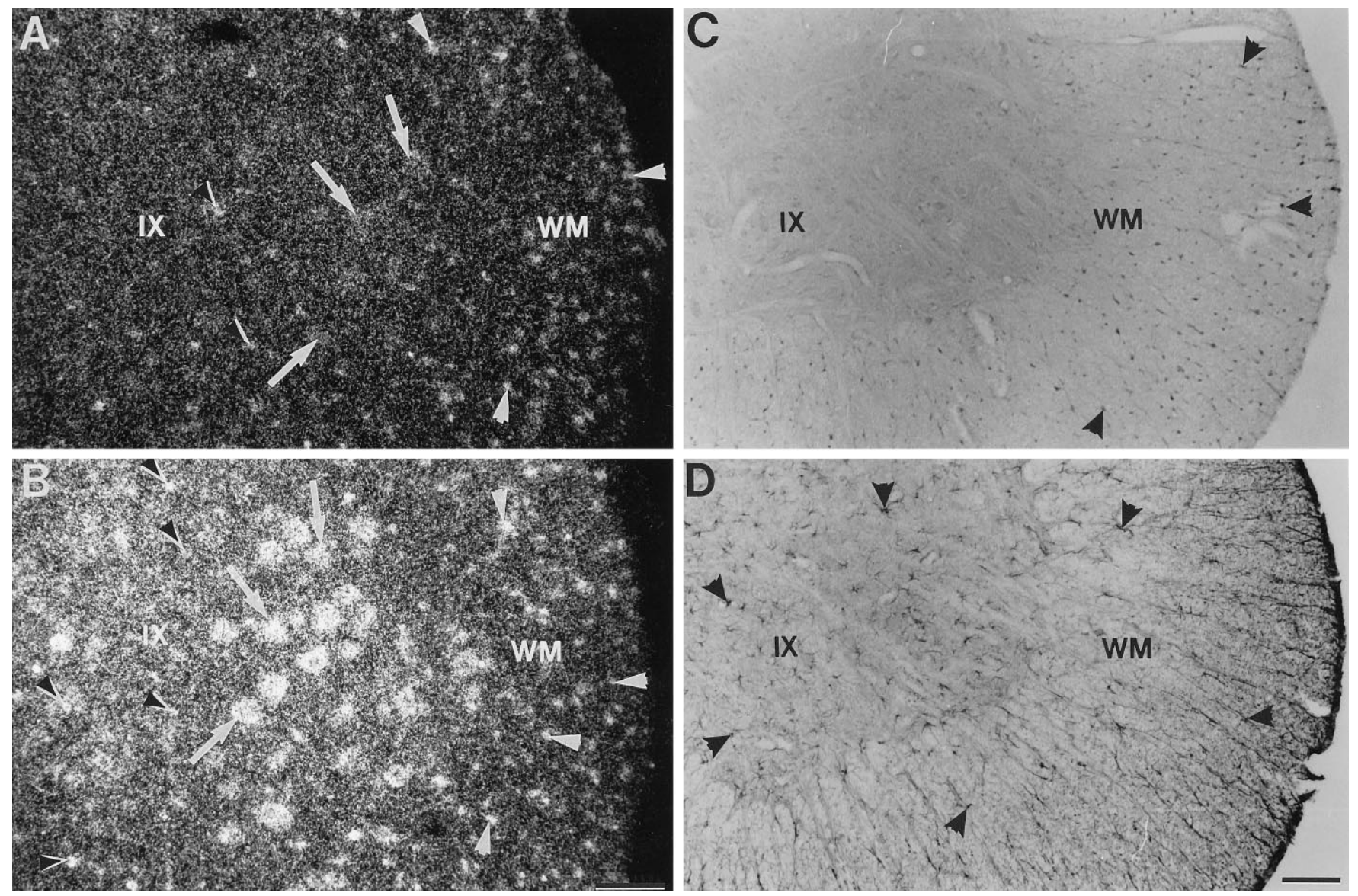

Figure 9. The distribution of white matter glia expressing high levels of MSP mRNA follow the distribution of CNPase-immunoreactive oligodendrocytes. Dark-field photomicrographs $(A, B)$ show the autoradiographic localization of MSP cRNA hybridization in association with the spinal motor neurons of lamina $I X$ (arrows) and in association with the glia of the white (white arrowheads) and gray matter (black and white arrowheads) of a control rat $(A)$ and a rat at $7 \mathrm{~d}(B)$ after kainic acid injury (see also Fig. $6 A, C)$. MSP-producing glia are most numerous in the white matter $(W M)$ and there follow the distribution of CNPase-immunoreactive oligodendrocytes (bright-field photomicrograph $C$, arrowheads) examined in parallel sections of control spinal cords. High levels of MSP cRNA labeling also were observed in a small fraction of gray matter glia in the spinal cord of control animals (black and white arrowheads in lamina $I X ; A, B)$; this contrasts with the number of GFAP-immunoreactive spinal cord glia in adjacent sections $(D)$. Significant increases in MSP cRNA hybridization persisted in the gray matter of the ventral horn at $7 \mathrm{~d}$ after KA exposure, including hybridization by motor neurons of lamina IX (arrows) and glia (black and white arrowheads; B). Scale bar, $100 \mu \mathrm{m}$.

at the neuromuscular junction leave this protease in a unique position to participate in remodeling of the neuromuscular synapse, under the control of the motor neuron itself. Although the endogenous inhibitors of MSP are unknown, one likely candidate may be neuroserpin, which is a trypsin-like protease inhibitor predominantly expressed by neurons and which has been shown to be released from axon terminals (Osterwalder et al., 1996).

\section{Role of MSP in the response of the spinal cord to excitotoxic injury}

The most convincing evidence for the role of serine proteases in neuronal degeneration caused by excitotoxic events comes from observations that KA injury causes an increase in tPA mRNA expression in hippocampal neurons and neuroglia and that tPA and plasminogen-deficient mice are resistant to KA-induced neuronal degeneration, as are animals treated with the plasminogen inhibitor $\alpha$-2-antiplasmin (Tsirka et al., 1995, 1997). We show that the novel serine protease MSP is present at high levels in the normal brain and spinal cord and is upregulated severalfold in spinal cord neurons and glia by KA-mediated excitotoxic injury. There is considerable evidence for a role of non-NMDA recep- tors in the response of the spinal cord white and gray matter to injury (Gomez-Pinilla et al., 1989; Rothstein et al., 1993; Wrathall et al., 1994; Agrawal and Fehlings, 1997). Further, it has been demonstrated in vitro that spinal motor neurons are selectively vulnerable to AMPA/kainate receptor-mediated injury because of the expression of AMPA/kainate receptors gating channels with direct $\mathrm{Ca}^{2+}$ permeability (Carriedo et al., 1996). Increases in MSP mRNA expression in the adult rat spinal cord were observed after the first $24 \mathrm{hr}$ after KA-induced injury and included glia of both the spinal cord white and gray matter. The activity of MSP therefore is likely to be associated with the more delayed response of the spinal cord to excitotoxic injury and may include expression by reactive astrocytes and microglia in addition to neurons and oligodendroglia. Together, these observations strongly suggest that MSP may affect neuronal survival and the regenerative environment of the injured adult spinal cord.

\section{REFERENCES}

Agrawal SK, Fehlings MG (1997) Role of NMDA and non-NMDA ionotropic glutamate receptors in traumatic spinal cord axonal injury. J Neurosci 17:1055-1063. 
Barde YA, Edgar D, Thoenen H (1983) New neurotrophic factors. Annu Rev Physiol 45:601-612.

Barradas PC, Gomes SS, Cavalcante LA (1995) CNPase expression in the developing opossum brain stem and cerebellum. NeuroReport 6:289-292.

Beecher KL, Andersen TT, Fenton II JW, Festoff BW (1994) Thrombin receptor peptides induce shape change in neonatal murine astrocytes in culture. J Neurosci Res 37:108-115.

Bell GI, Quinto C, Quiroga M, Valenzuela P, Craik CS, Rutter WJ (1984) Isolation and sequence of a rat chymotrypsin B gene. J Biol Chem 259:14265-14270.

Blaber M, Isackson PJ, Bradshaw RA (1987) A complete cDNA sequence for the major epidermal growth factor binding protein in the male mouse submandibular gland. Biochemistry 26:6742-6749.

Blondet B, Barlovatz-Meimon G, Festoff BW, Soria C, Soria J, Rieger F, Hantai D (1992) Plasminogen activators in the neuromuscular system of the wobbler mutant mouse. Brain Res 580:303-310.

Cadelli DS, Bandtlow CE, Schwab ME (1992) Oligodendrocyte- and myelin-associated inhibitors of neurite outgrowth: their involvement in the lack of CNS regeneration. Exp Neurol 115:189-192.

Carriedo SG, Yin HZ, Weiss JH (1996) Motor neurons are selectively vulnerable to AMPA/kainate receptor-mediated injury in vitro. J Neurosci 16:4069-4079.

Carroll PM, Tsirka SE, Richards WM, Frohman MA, Strickland S (1994) The mouse tissue plasminogen activator gene 5' flanking region directs appropriate expression in development and a seizure-enhanced response in the CNS. Development 120:3173-3183.

Cavanaugh K, Gurwitz D, Cunningham DD, Bradshaw R (1990) Reciprocal modulation of astrocyte stellation by thrombin and protease nexin-1. J Neurochem 54:1735-1743.

Chen ZL, Yoshida S, Kato K, Momota Y, Suzuki J, Tanaka T, Ito J, Nishino H, Aimoto S, Kiyama H, Shiosaka S (1995) Expression and activity-dependent changes of a novel limbic-serine protease gene in the hippocampus. J Neurosci 15:5088-5097.

Chirgwin JM, Przbyla AE, MacDonald RJ, Rutter WJ (1979) Isolation of biologically active ribonucleic acid from sources enriched in ribonuclease. Biochemistry 118:5294-5299.

Danielson P, Forss-Pette RS, Brow MA, Calavetta L, Douglass J, Milner RJ, Sutcliffe JG (1988) p1B15: a cDNA clone of the rat mRNA encoding cyclophilin. DNA 7:261-267.

David S, Aguayo AJ (1981) Axonal elongation into peripheral nervous system "bridges" after central nervous system injury in adult rats. Science 214:931-933.

Degen SJ, Rajput B, Reich E (1986) The human tissue plasminogen activator gene. J Biol Chem 261:6972-6985.

Festoff BW, Hantai D, Soria J, Thomaidis A, Soria C (1986) Plasminogen activator in mammalian skeletal muscle: characteristics of effect of denervation on urokinase-like and tissue factor. J Cell Biol 103:1415-1421.

Festoff BW, Rao JS, Hantai D (1991) Plasminogen activators and inhibitors in the neuromuscular system. III. Their serpin protease nexin I is synthesized by muscle and localized to the neuromuscular synapse. J Cell Physiol 147:76-86.

Festoff BW, Nelson PG, Brenneman DE (1996) Prevention of activitydependent neuronal death: vasoactive intestinal polypeptide stimulates astrocytes to secrete the thrombin-inhibiting neurotrophic serpin, protease nexin I. J Neurobiol 30:255-266.

Frey U, Muller M, Kuhl D (1996) A different form of long-lasting potentiation revealed in tissue plasminogen activator mutant mice. J Neurosci 16:2057-2063.

Gomez-Pinilla F, Tram H, Cotman CW, Nieto-Sampedro M (1989) Neuroprotective effect of MK-801 and U-50488H after contusive spinal cord injury. Exp Neurol 104:118-124.

Gurwitz D, Cunningham DD (1988) Thrombin modulates and reverses neuroblastoma neurite outgrowth. Proc Natl Acad Sci USA 85:3440-3444.

Gurwitz D, Cunningham DD (1990) Neurite outgrowth activity of protease nexin-1 on neuroblastoma cells requires thrombin inhibition. J Cell Physiol 142:155-162.

Hantai D, Rao JS, Festoff BW (1990) Rapid neural regulation of muscle urokinase-like plasminogen activator as defined by nerve crush. Proc Natl Acad Sci USA 87:2926-2930.

Hatten ME, Liem RKM, Mason CA (1984) Two forms of cerebellar glial cells interact differently with neurons in vitro. J Cell Biol 98:193-204.
Houenou L, Turner PL, Li L, Oppenheim RW, Festoff BW (1995) A serine protease inhibitor, protease nexin I, rescues motoneurons from naturally occurring and axotomy-induced cell death. Proc Natl Acad Sci USA 92:895-899.

Krystosek A, Seeds NW (1981) Plasminogen activator release at the neuronal growth cone. Science 213:1532-1534.

Lindsay RM (1979) Adult rat brain astrocytes support survival of both NGF-sensitive and -insensitive neurons. Nature 282:80-82.

Liu Y, Fields DR, Festoff BW, Nelson PG (1994a) Proteolytic activity of thrombin is required for electrical activity-dependent synapse reduction. Proc Natl Acad Sci USA 91:10300-10304.

Liu Y, Fields RD, Fitzgerald S, Festoff BW, Nelson PG (1994b) Proteolytic activity, synapse elimination, and the Hebb synapse. J Neurobiol 25:325-335.

MacDonald RJ, Stary SJ, Swift GH (1982) Two similar but nonallelic rat pancreatic trypsinogens. Nucleotide sequences of the cloned cDNAs. J Biol Chem 257:9724-9732.

Matrisian LM, Hogan BL (1990) Growth factor-regulated proteases and extracellular matrix remodeling during mammalian development. Curr Top Dev Biol 24:219-259.

McGuire PG, Seeds NW (1990) Degradation of underlying extracellular matrix by sensory neurons during neurite outgrowth. Neuron 4:633-642.

Meier R, Spreyer P, Ortmann R, Harel A, Monard D (1989) Induction of glia-derived nexin after lesion of a peripheral nerve. Nature 342:548-550.

Monard D (1988) Cell-derived proteases and protease inhibitors as regulators of neurite outgrowth. Trends Neurosci 11:541-544.

Moonen G, Grau-Wagemans M-P, Selack I (1982) Plasminogen activator-plasmin system and neuronal migration. Nature 298:753-755.

Murtomaki S, Trenkner E, Wright JM, Saksela O, Liesi P (1995) Increased proteolytic activity of the granule neurons may contribute to neuronal death in the weaver mouse cerebellum. Dev Biol 168:635-648.

Nakajima K, Reddington M, Kohsaka S, Kreutzberg GW (1996) Induction of urokinase-type plasminogen activator in rat facial nucleus by axotomy of the facial nerve. J Neurochem 66:2500-2505.

Neveu I, Jehan F, Jandrot-Perrus M, Wion D, Brachet P (1993) Enhancement of the synthesis and secretion of nerve growth factor in primary cultures of glial cells by proteases: a possible involvement of thrombin. J Neurochem 60:858-867.

Osterwalder T, Contartese J, Stoeckli ET, Kuhn TB, Sonderegger P (1996) Neuroserpin, an axonally secreted serine protease inhibitor. EMBO J 15:2944-2953.

Pittman RN, Williams A (1989) Neurite penetration into collagen gels requires $\mathrm{Ca}^{2+}$-dependent metalloproteinase activity. Dev Neurosci 11:41-51.

Prineas JW, Kwon EE, Goldenberg PZ, Ilyas AA, Quarles RH, Benjamins JA, Sprinkle TJ (1989) Multiple sclerosis. Oligodendrocyte proliferation and differentiation in fresh lesions. Lab Invest 61:489-503.

Qian Z, Gilbert ME, Colicos MA, Kandel ER, Kuhl D (1993) Tissueplasminogen activator is induced as an immediate-early gene during seizure, kindling, and long-term potentiation. Nature 361:453-457.

Rao JS, Beach RL, Festoff BW (1985) Extracellular matrix synthesis in muscle cell cultures: quantitative and qualitative studies during myogenesis. Biochem Biophys Res Commun 130:440-446.

Reynolds R, Carey EM, Herschkowitz N (1989) Immunohistochemical localization of myelin basic protein and $2^{\prime}, 3^{\prime}$-cyclic nucleotide $3^{\prime}$ phosphohydrolase in flattened membrane expansions produced by cultured oligodendrocytes. Neuroscience 28:181-188.

Rickles RJ, Darrow AL, Strickland S (1988) Molecular cloning of complementary DNA to mouse tissue plasminogen activator mRNA and its expression during F9 teratocarcinoma cell differentiation. J Biol Chem 263:1563-1569.

Rothstein JD, Jin L, Dykes-Hoberg M, Kuncl RW (1993) Chronic inhibition of glutamate uptake produces a model of slow neurotoxicity. Proc Natl Acad Sci USA 90:6591-6595.

Sambrook J, Fritsch EF, Maniatis T (1989) Molecular cloning: a laboratory manual, 2nd Ed. Cold Spring Harbor, NY: Cold Spring Harbor Laboratory.

Sanes JR (1983) Roles of extracellular matrix in neural development. Annu Rev Physiol 45:581-600.

Sanes JR (1989) Extracellular matrix molecules that influence neural development. Annu Rev Neurosci 12:491-516.

Sappino A-P, Madani R, Huarte J, Belin D, Kiss JZ, Wohlwend A, 
Vassalli J-D (1993) Extracellular proteolysis in the adult murine brain. J Clin Invest 92:679-685.

Scarisbrick IA, Jones EG, Isackson P (1993) Coexpression of mRNAs for NGF, BDNF, and NT-3 in the cardiovascular system of the pre- and postnatal rat. J Neurosci 13:875-893.

Scherer SS, Braun PE, Grinspan J, Collarini E, Wang D-Y, Kamholz J (1994) Differential regulation of the $2^{\prime}, 3^{\prime}$-cyclic nucleotide $3^{\prime}$ phosphodiesterase gene during oligodendrocyte development. Neuron 12:1363-1375.

Seeds N, Haffke S, Christensen K, Schoonmaker J (1990) Cerebellar granule cell migration involves proteolysis. Adv Exp Med Biol 265:169-178

Seeds NW, Williams BL, Bickford PC (1995) Tissue plasminogen activator induction in Purkinje neurons after cerebellar motor learning. Science 270:1992-1994.

Shotton DM, Watson HC (1970) The three-dimensional structure of crystalline porcine pancreatic elastase. Philos Trans R Soc Lond [Biol] 257:111-118.

Smith-Swintosky VL, Zimmer S, Fenton II JW, Mattson MP (1995)
Protease nexin- 1 and thrombin modulate neuronal $\mathrm{Ca}^{2+}$ homeostasis and sensitivity to glucose deprivation-induced injury. $\mathrm{J}$ Neurosci 15:5840-5850.

Sumi Y, Dent MAR, Owen DE, Seely PJ, Morris RJ (1992) The expression of tissue and urokinase plasminogen activators in neural development suggests different modes of proteolytic involvement in neuronal growth. Development 116:625-637.

Tsirka SE, Gualandris A, Amaral DG, Strickland S (1995) Excitotoxininduced neuronal degeneration and seizure are mediated by tissue plasminogen activator. Nature 377:340-344.

Tsirka SE, Rogove AD, Bugge TH, Degan JL, Strickland S (1997) An extracellular proteolytic cascade promotes neuronal degeneration in the mouse hippocampus. J Neurosci 17:543-552.

Ware JH, DiBenedetto AJ, Pittman RN (1995) Localization of tissue plasminogen activator mRNA in adult rat brain. Brain Res Bull 37:275-281.

Wrathall JR, Choiniere D, Teng YD (1994) Dose-dependent reduction of tissue loss and functional impairment after spinal cord trauma with the AMPA/kainate antagonist NBQX. J Neurosci 14:6598-6607. 